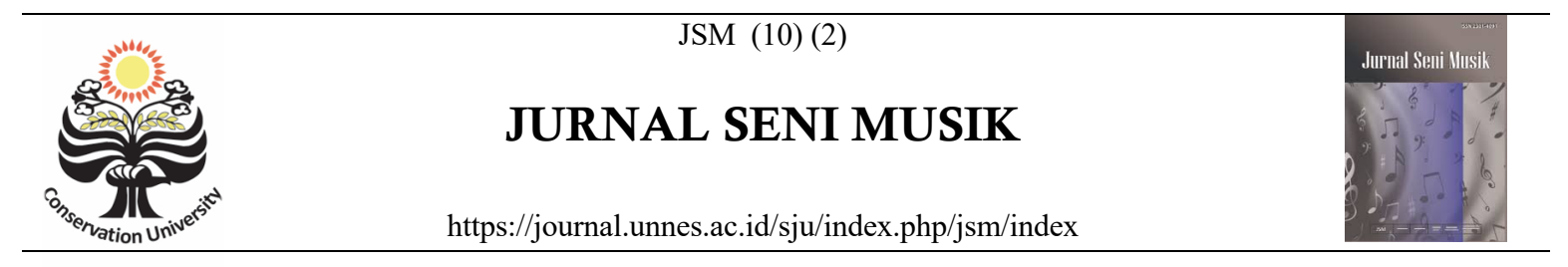

\title{
Students' Reception To Creation Puppet Music Of Hikayat Banjar
}

\section{Dewi Alfianti}

Faculty of Teacher Training and Education, Universitas Lambung Mangkurat, Banjarmasin Muhammad Budi Zakia Sani ${ }^{\otimes 1}$

Faculty of Teacher Training and Education, Universitas Lambung Mangkurat, Banjarmasin

\section{Article Info}

Submitted : November, 2021

Revised : November,2021

Accepted:December,2021

Keywords:

Puppet Music, Hikayat Banjar
Abstract

Hikayat Banjar as a literary treasure with a mix of history and myths about the origin of the Banjar people is not well known to the younger generation of South Kalimantan. In fact, from the Hikayat Banjar, we can know the central role of the river as a wetland landscape. This research tries to revitalize the Hikayat Banjar in the form of a puppet creation video that contains the final part of the Hikayat Banjar music which is related to the history of the founding of the Banjar kingdom. This video was shown and watched by students of SMA Islam Terpadu Ukhuwah class XI. After watching the video, they were asked to answer questions about how they saw the show about the Hikayat Banjar which they had watched. From the results, it is known that there is a great relationship between Hikayat Banjar and the students' knowledge about the show. It is proven, only $56 \%$ of students know about Hikayat Banjar. However, this video itself was received positively by students and became their reference in understanding certain parts of the Banjar Hikayat. Meanwhile, the role of the river in the Hikayat Banjar is considered important by the respondents. Ninety-six percent of respondents agree that rivers play an important role, both socially and politically. Both are a means of regional development, as well as a battle arena. This study uses a descriptive approach to describe and view audience data in the questionnaire that has been filled out. The results show how Hikayat Banjar music position is on the horizon of audience reception. 


\section{INTRODUCTION}

To understand the origins of Banjar as a culture and civilization, we need to refer to two manuscripts, namely Hikayat Banjar and Tutur Candi. Hikayat Banjar and Tutur Candi are two different versions of the origin story of the Banjar kingdom from the beginning formation until the time of Sultan Suriansyah and his descendants.

Dutch philologists distinguish between Hikayat Banjar and Tutur Candi as two sources with different intensities. Hikayat Banjar is also called Review 1 that is considered more 'academic' because the narration can be traced in writing, from one manuscript to other manuscripts. Hikayat Banjar was made by the palace circles to legitimize its power so it is palace-centric. Meanwhile, Tutur Candi is considered a more flexible version from Hikayat Banjar.

Story Tutur Candi in line with Hikayat Banjar, but only consists of 11 episodes. Tutur Candi does not discuss the Keraton IV phase. Parts of each episode of Tutur are similar to Hikayat Banjar but it's just with a long and convoluted version. It has a lot inserted fantastic things. However, in certain parts, it complements the lack of information which is on Hikayat Banjar. Some important developments or information contained in Tutur Candi helps the reader to understand the whole kingdom narration of Banjar - especially in the beginning parts.

For example, episode 1 of Hikayat Banjar doesn't tell about the background of Ampu Jatmika family but Tutur Candi reviews it at length, including popular figures in Islam such as Sultan Iskandar and Nabi (Hadir) Khidir as part of the Ampu Jatmika's family tree. It shows that the influence of Islam is also felt in the oral narration version as an older version of the manuscript version. Additional description is also found in Tutur Candi in the second episode namely, the appearance of the name Kuripan as a local ruler in the Banua Hujung land before Ampu Jatmika came. Besides additions, Tutur Candi also is found differences in the explanation of the lineage of the descendants of Maharaja Suryanata and Queen Junjung Buih.
JJ Rass (1993:75) explains the fundamental difference in Hikayat Banjar and Tutur Candi is located in (1) storytelling style, Hikayat Banjar is more concise while Tutur Candi is long-winded and contains more magic things out of mind (Rass calls it version romanticized); (2) Hikayat Banjar Review 1 is a palace text made in the palace environment to legitimize the power of the parts in the palace, while Tutur Candi is a puppet text that is widely circulated in the community through folk theater performances Abdul Muluk. With their respective pressure points, Hikayat Banjar more contains information on organizational work procedures and palace customs such as how to behave, dress, and explanation of symbols and social status.

This introduction can be done by making it an educational show, by using the existing audiovisual technology. To become an interesting show, Hikayat Banjar needs to be transformed into a more interesting form. Storytelling visually and auditively needs to be done to obtain material that can be documented audiovisually.

In this study, the Hikayat Banjar media transfer video will be watched by class XI, SMA IT (Islam Terpadu) Ukhuwah Banjarmasin. The researcher chose the students from SMA IT (Islam Terpadu) Ukhuwah Banjarmasin because the content of the video containing the conversion incident of the people of the Banjar kingdom to Islam as an excess of the agreement with Demak and their understanding of river culture in Hikayat Banjar. Furthermore, this paper will look at how students' reception of Hikayat Banjar itself and its relation to the river as part of the background of the story.

\section{METHOD}

The approach used in this research is qualitative. By this approach, the researcher analyzed the data using the qualitative research construct. The data in this study are the results of the reception of class XI students at SMA IT Ukhuwah Banjarmasin for the video of Hikayat 
Banjar creation puppet which is a media transfer (ecranisation) from the book Hikayat Banjar arranged by JJ Rass. The sources of the data are the students of class XI at SMA IT Ukhuwah Banjarmasin who filled out the research questionnaire.

Data collection in this study using a questionnaire. The researcher asked the readers for some feedback. The researcher was not involved in these observations, only as an outside observer. The collection procedure is carried out with the following steps as follows, (1) giving a Google form introduction questionnaire to students a few days before the show, (2) showing the creation puppet video created by Hikayat Banjar to students, (3) giving students time to understand and interpret the video, (4) providing a reader reception google form questionnaire for students to fill out, (5) collecting data from the questionnaire. The data is in the form of the results of questionnaires filled out by students, (6) the questionnaire itself will contain questions related to reading, understanding, and interpretation from the reader to the videos they watched.

\section{RESULTS AND DISCUSSIONS}

\section{Banjar \\ The Musical Forms of Hikayat}

The form of music in this work is the result of studio work conducted by the composer. This work took almost 2 weeks of processing and editing, mixing, then mastering process. The form or concept of the music made in this work is a collaboration between elements of Banjar traditional music with western music (theater music). The instrumentation used is dominant in the Banjar Gamelan which is arranged as the main idea in the musical composition, then the content of the strings, and sounds of the other atmosphere that are as support or as an illustration.

The music consists of several parts arranged systematically following the plot of the story of Hikayat Banjar. The beginning of the music amplifies the atmosphere of Banjar presented in the script, then interpreted into an interesting and appropriate audio-visual. In the middle and the end, there are many repetitions done for emphasizing the atmosphere of the story that has been created.

Reception Results

Results

The Introduction Questionnaire

Before submitting a questionnaire related to student reception of the video Puppet creations by Hikayat Banjar, the researcher first distributed a preliminary questionnaire. The introduction questionnaire contains several background-related questions that need to be explored by respondents.

From 110 students of class XI at SMA IT Ukhuwah Banjarmasin, 50 of them filled out the Google form shared. The number of questions asked are as follows:

\section{Respondent's tribe}

From the variety of answers, respondents only mention two types of ethnic groups, namely Banjar and Javanese in which Banjar tribe is more dominant with a presentation of almost $90 \%$. By a background dominated by the Banjarese, it is hoped that respondents will feel more familiar with the video shown. Banjar ethnic background is also expected to be a binding power emotionally between the response and the video watched.

2. Previous Information about Hikayat Banjar

About $44 \%$ of respondents never knew about Hikayat Banjar, while 56\% never heard. It shows that almost half of the respondents are still strange or less familiar with the Hikayat Banjar. The horizon of hope between the readers knowing Hikayat Banjar and those who don't know surely will be different. What expectations from both categories of these readers are influenced by their previous interactions with Hikayat Banjar.

3. Identifying the Names of Banjar Hikayat Character

From the eleven characters in Hikayat Banjar, the character that the 
respondents know well is Sultan Suriansyah who is widely known as the founder of the Banjar Kingdom. Sultan Suriansyah died in a location that is widely known to the public and the location is still frequently visited nowadays. Other characters who are well known to the respondents are Putri Junjung Buih and Patih Lambung Mangkurat, both of them are still categorized as fictional characters because there is no historical evidence that indicates that they both once lived although they are quite popular as one of the widely known mythical figures in the Banjar community.

\section{Introduction to Wetlands}

Sixty-two percent of respondents, which means more than half of the respondents, stated that they never knew the term wetland. It is like in the question about the introduction of Hikayat Banjar. It will affect the horizon of readers' expectations of the content wetland information in the video will be shown.

Introduction questions that had been made will make it easier for the researcher and respondents. By providing an early overview of what will be broadcast, the respondent will have prior knowledge of what he or she might expect after watching. In addition, the researcher got a clear initial overview regarding the respondent's knowledge related to the video that will be shown.

The Execution of the Video Show

The Puppet video created by Hikayat Banjar was shown via the Zoom conference application on Friday on September 17th in 2021 at 10.00-11.00. This activity was attended by 100 participants consisting of students and teachers of class XI at SMA IT Ukhuwah. This activity begins with an explanation about Hikayat Banjar by the researcher. The students listen to the researcher's presentation explaining Hikayat Banjar: what Hikayat of Banjar is, who composed it, and what the content of the Hikayat Banjar story is.

After explaining for 20 minutes. The researcher showed creation puppet videos of Hikayat Banjar for 15 minutes.
The problem occurs because of a less stable network problem. Several students reported that the video they watched was not smooth when it was shown.

After the students watched, the activity continued with a discussion about the film. The questions are appointed by a teacher and a student. The teacher asks about the role of Demak in the war between Prince Samudra and Maharaja Tumanggun. Meanwhile, the student asked about Hindu customs in the Banjar community which had been Islamized. These two questions are related to the part of the story where Prince Samudra has been crowned as the King of Banjar. This question refers to the Hikayat Banjar episode 11 whose story is very popular with the community, namely the Islamization of the Banjar kingdom which is an agreement between Banjar and Demak. The creation puppet video plays a role to visualize the story in order to internalize it easily for the audiences.

After the Q\&A session was over, the activity ended with a request from the researcher to student audiences who are willing to fill out a questionnaire related to the video shown. The activity was closed by taking a picture together in the Zoom room.

The Students' Perspectives on Hikayat Banjar

Based on the reception results of class XI students at SMA IT Ukhuwah Banjarmasin, it can be seen that there is a large gap between the existence of Hikayat Banjar and the students' knowledge about that. As a manuscript, Hikayat Banjar contains myths and history about the establishment of kingdoms in the South Kalimantan region, namely Kerajaan Negara Dipa, Kerajaan Negara Daha, dan Kerajaan Banjar, where the kingdoms are related in terms of inheritance of power from generation to generation. Thus, even though it was mixed with myths, Hikayat Banjar contains an initial narrative about the identity of Banjarese which means it can be an important reference related to the history of Banjar. 
Despite having an important position in the structure of Banjar sociocultural knowledge, only $56 \%$ of respondents knew this story previously. Almost half of the respondents did not know about this Banjar Hikayat. Therefore, its introduction is important. The show of the creation puppet video of Hikayat Banjar is expected to help build the respondents' understanding. After showing the video, $89 \%$ of respondents said that it helped them understand the Hikayat Banjar better. This video has a positive response with $81.9 \%$ of respondents considering the story interesting. The high level of interest in videos shows that the audiovisual shows are indeed appropriate and more suitable for the respondents with the adolescent age range about 16-17 years and the education at the level of Junior High School class XI.

The respondents' good understanding of the video content is shown by the relevance of the selection of protagonists and antagonists with the storyline. From 38 respondents, only one person called Prince Tumenggung an antagonist, the others called the protagonist characters are Prince Samudra and several other characters. The respondents can also explain what lessons can be drawn from this episode in Hikayat Banjar. The interpretation of Hikayat Banjar brings them to an understanding of what lessons can be learned from this story including the greedy character of the power that exists in humans and the sense of envy that destroys human values. Meanwhile, 9 respondents re-emphasized strengthening the understanding of Hikayat Banjar itself as a lesson that can be taken from the creation puppet video of Hikayat Banjar. Thus, the purpose of showing as an introduction medium of Hikayat Banjar on respondents who are the younger generation with a level of the gap so far from the Hikayat Banjar text has been fulfilled.

The Students' Perspective on the River

In addition to understanding the respondent about Hikayat Banjar, especially at the beginning of the Banjar Kingdom establishment, the video viewing is also intended to see how respondents can find the relevance of the story with the river background as a geographic span of wetland.

There are two questions used to see the respondents' understanding of Hikayat Banjar relevance and the river background in the story. The first question is related to the attendance of the river in the story. The response to find the river is a vital element in the escape process of Prince Samudra which is carried out by a river, not by land. It shows that at that time, the river became an important route in public transportation routes. In the story of Prince Samudra's journey, it is stated that he went through alternative routes less traveled so that he could hide safely from the search for his uncle. The existence of an alternative route shows that as an important transportation route, rivers have been optimized to form alternative paths.

The location of the kingdom, Kerajaan Negara Daha, and the new Banjar kingdom, always close to the port and the river. Even Kerajaan Negara Daha told in the early episodes of Hikayat Banjar, the location is also close to the river. River to be vital as understood by the respondents. About $94,7 \%$ of respondents agree about the vital role of this river for each kingdom.

The vital role of rivers is related to their position as transportation and trading routes. Even the battle between Prince Samudra and Maharaja Tumenggung was carried out in rivers and harbor areas. Making the river a battlefield shows the view that rivers are considered to have a strategic position in various ways.

\section{CONCLUSION}

From the results of the reception, it can be seen that there is a large gap between the existence of Hikayat Banjar existence and the knowledge of the students of class XI at SMA IT Ukhuwah Banjarmasin. This is proven, only $56 \%$ of students know about HIkayat Banjar. 
However, this video itself was received positively by students and became their reference in understanding certain parts of the Hikayat Banjar.

Meanwhile, the role of the river in the Hikayat Banjar is considered important by the respondents. About $96 \%$ of respondents agree that rivers play an important role in social and political aspects as a means of regional development and a battle arena.

\section{REFERENCES}

Pradopo, Rahmat Djoko. (2017). Beberapa Teori Sastra: Metode, Kritik, dan Penerapannya. Yogyakarta: UGM Press.

Rass, J.J. (1968). Hikayat Banjar (Siti Hawa Salleh, trans). Malaysia: Percetakan Dewan Bahasa dan Pustaka.

Moleong, Lexy J. 2001. Metodologi Penelitian Kualitatif. Bandung: Remaja Rosdakarya.

Saleh, Muhammad Idwar (1986). Tutur Candi. Jakarta: Perpustakaan Nasional \& Balai Pustaka

Suryanata, Jamal T. 2016. Pendekatan Kajian Sastra: Sebuah Pengantar Ringkas. Banjarbaru: Scripta Cendikia. 